\title{
Assessment of Growing Media on Vegetative, Flowering and Vase Life Characteristics of Lilium (Lilium longiflorum) cvs. Bach and Pavia in the Foothills of Himalayas
}

\author{
Narendra Singh Bhandari \\ Department of Horticulture, G.B. Pant University of Agriculture \& Technology, \\ Pantnagar-263 145 (Uttarakhand), India \\ Ranjan Srivastava (Corresponding author) \\ Department of Horticulture, G.B. Pant University of Agriculture \& Technology, \\ Pantnagar-263 145 (Uttarakhand), India \\ E-mail: ranjansrivastava25@gmail.com
}

Received: February 6, 2016 Accepted: February 29, 2016 Published: March 1, 2016

Doi: $10.5296 /$ jab.v4n1.9118

URL: http://dx.doi.org/10.5296/jab.v4n1.9118

\begin{abstract}
The experiment was carried out to investigate the effect of different growing media on vegetative, flowering and vase life characteristics of two LA lily hybrids Bach and Pavia in 2 factorial randomized block design with three replications. Of the two factors, first factor was two varieties namely, Bach and Pavia and the second factor was five growing media including (1) garden soil, (2) cocopeat, (3) cocopeat + sand (1:1) and (4) garden soil + sand $(1: 1)$. However, bulbs of LA lily hybrids were planted in plastic crates containing different growing media with 10 bulbs in each crate, placed inside 50 percent shadenet house. Final plant height $(116.63 \mathrm{~cm}$.) and number of flower buds (7.27) was highest in cv. Pavia at 60 days after planting. However, quickest flower bud appearance (29.53days) and maximum vase life (11.26 days) was in cv. Bach. Among the potting media, cocopeat found to be superior for enhancing all characteristics along with both the cultivars.
\end{abstract}

Keywords: Lily, Variety, Growing media, Plant height, Flower bud, Vase life 


\section{Introduction}

Lilies are a symbol of pure and fruitful life. Lilium is a unique ornamental plant with many colorful flowers (Shiravand \& Rostami, 2009). The genus Lilium includes herbaceous flowering plants growing from non tunicate scaly bulbs belongs to family Liliaceae. Because of its high profitability within short time of 3-4 months, new generation of farmer and entrepreneur are getting attracted toward its cultivation. In recent year, soilless culture or substrate culture has been recognized as advance system in floriculture industry for producing quality flowers. Thus, selection of suitable substrates is one of the most important factors in creating a soilless culture system that's why this study was carried out. Growing media play important role in supporting and building up of plant body. Studies have revealed that incising the proportion of potting media like cocopeat improve all growth indices particularly plant height, stem diameter, flower diameter, and number of buds (Seyedi et al., 2012). Cocopeat alone or with other substrates are used as a culture medium. In heavy soils without enough drainage, the development of root system is suppressed and plants are more susceptible to soil borne diseases (Beattie \& White, 1992). Cocopeat has good physical properties, high total pore space, high water content, low shrinkage, low bulk density and slow biodegradation (Evans et al., 1996).

\section{Materials and Methods}

The present study was carried out at Model Floriculture Center of the University located in Tarai region in foothills of Himalaya at an altitude of 243.84 meters above mean sea level. The physico-chemical properties of growing media components were determined before planting of bulbs. The electrical conductivity (EC) and $\mathrm{pH}$ of substrate were determined by using EC Systronics Conductivity Meter and Digital $\mathrm{pH}$ Meter, respectively.

The experiment was arranged in a 2 factorial randomized block design with three replications. First factor included two commercial cultivars of LA hybrid lilies Bach and Pavia. Second factor was growing medium which included (1) garden soil, (2) cocopeat, (3) cocopeat + sand (1:1) and (4) soil + sand (1:1). Sprouted bulbs of 'Bach' and 'Pavia' of 14-16 grades in circumference were planted in plastic crates containing different potting media. Ten bulbs per crate were raised in a 50 per cent shadenet house from January to July, 2015. The data pertaining to vegetative and floral characters was recorded on randomly selected five plants from each variety in each of three replications. The standard methods for recording different growth and flowering parameters were used. The flower spike was harvested in the morning and at the stage when lower most bud was fully turgid and had changed its colour from green to white and yellow. The flower stems were kept in vase containing distilled water at ambient conditions and observations for vase life were recorded till last bud showed senescence.

\section{Results and Discussion}

Plant height: A perusal of data pertaining to plant height presented in Table 1 reveals that plant height was significantly affected by variety, growing media and their interaction. Barring growing media, at 15 days of bulb sowing, plant heights of cv Bach and Pavia were statistically at par. However, plant heights of Pavia plants were significantly higher than Bach plants at 30, 45 and 60 days of bulb sowing. Among different growing media irrespect of variety, the plant heights in cocopeat $\left(\mathrm{T}_{2}\right)$ grown plants were significantly higher than all 


\section{Al Macrothink}

other growing media and plant heights were minimum in sol raised plants (Table 1). Among interactions, of variety with growing media, the plants of Pavia in cocopeat $\left(\mathrm{V}_{2} \mathrm{~T}_{2}\right)$ attained maximum plant height at all growing stages $(15,30,45$ and 60 days). The pant heightbis a varietal character and is also affected by the growing meida which facilitates better growing conditions and availability of nutrients and water. Tribulato and Noto (2001) also reported that using a mixture of peat and basalt increases length of flower stem in lilium. Moghadam and Shoor (2013) reported that growth, yield and quality of petunia (Petunia hybrida) significantly affected by different treatments. The plants receiving Azospirillum sp. + Phosphate solubilizing bacterium + vermi-compost + NPK $(25 \%$ of recommended dose $)]$ treatment, recorded maximum plant height $(82.87 \mathrm{~cm})$.

Days to appearance for flower buds: Among the varieties, the maximum number of days (33.77 days) was required for flower bud initiation in var. Pavia whereas minimum days (30.57 days) were taken in Bach. However, the difference was non-significant. Among the potting mixture, plants raised on cocopeat took minimum days (31.10) which were significantly earlier than rest of the treatments. The interaction among growing media treatment and variety was non-significant. However, the days to appearance of flower buds were earliest (29.53 days) in $\mathrm{V}_{1} \mathrm{~T}_{2}$. Tehranifar et al. (2011) also investigated three soilless media on growth and development of two types of Lilium (Asiatic and Oriental hybrids, cultivars 'Gironde' and 'Cassandra', respectively). The time of bud emergence and flower harvest were 8-9 days earlier in 'Gironde', than 'Cassandra'.

Table 1. Periodic changes in plant height of Lilium cv. Bach and Pavia as influenced by potting media

\begin{tabular}{|c|c|c|c|c|c|c|c|c|c|c|c|c|}
\hline \multirow{3}{*}{ Treatments } & \multicolumn{12}{|c|}{ Plant height (cm) } \\
\hline & \multicolumn{3}{|c|}{15 days } & \multicolumn{3}{|c|}{30 days } & \multicolumn{3}{|c|}{45 days } & \multicolumn{3}{|c|}{60 days } \\
\hline & $\begin{array}{l}\text { Bach } \\
\text { (Vl) }\end{array}$ & $\begin{array}{c}\text { Pavia } \\
\text { (V2) }\end{array}$ & Mean & $\begin{array}{l}\text { Bach } \\
\text { (Vl) }\end{array}$ & $\begin{array}{l}\text { Pavia } \\
\text { (V2) }\end{array}$ & Mean & $\begin{array}{l}\text { Bach } \\
\text { (Vl) }\end{array}$ & $\begin{array}{l}\text { Pavia } \\
\text { (V2) }\end{array}$ & Mean & $\begin{array}{l}\text { Bach } \\
\text { (Vl) }\end{array}$ & $\begin{array}{l}\text { Pavia } \\
\text { (V2) }\end{array}$ & Mean \\
\hline $\operatorname{Soil}\left(\mathrm{T}_{1}\right)$ & 17.60 & 24.60 & 21.10 & 46.30 & 52.00 & 49.15 & 82.96 & 88.26 & 85.61 & 93.33 & 97.16 & 95.25 \\
\hline Cocopeat $\left(\mathrm{T}_{2}\right)$ & 23.56 & 26.20 & 24.88 & 51.96 & 56.20 & 54.08 & 87.40 & 95.46 & 91.43 & 105.0 & 116.63 & 110.81 \\
\hline $\begin{array}{l}\text { Cocopeat }+ \\
\text { Sand }(1: 1)\left(T_{3}\right)\end{array}$ & 18.86 & 22.73 & 20.80 & 48.90 & 54.26 & 51.58 & 84.73 & 88.33 & 86.53 & 102.13 & 101.43 & 101.78 \\
\hline $\begin{array}{l}\text { Cocopeat + Soil } \\
(1: 1)\left(T_{4}\right)\end{array}$ & 18.50 & 23.26 & 20.88 & 49.70 & 54.16 & 51.93 & 83.10 & 88.26 & 85.68 & 98.80 & 103.46 & 101.13 \\
\hline \multirow[t]{2}{*}{ Mean } & 19.63 & 24.20 & 21.91 & 49.21 & 54.15 & 51.68 & 84.55 & 90.08 & 87.31 & 99.81 & 104.67 & 102.24 \\
\hline & $\begin{array}{l}\text { Variety } \\
\text { (V) }\end{array}$ & $\begin{array}{l}\text { Treatment } \\
\text { (I) }\end{array}$ & $\mathbf{V} \times \mathbf{T}$ & $\begin{array}{l}\text { Variety } \\
\text { (V) }\end{array}$ & $\begin{array}{l}\text { Treatment } \\
\text { (I) }\end{array}$ & $\mathbf{V} \times \mathbf{T}$ & $\begin{array}{l}\text { Variety } \\
\text { (V) }\end{array}$ & $\begin{array}{l}\text { Treatment } \\
\text { (T) }\end{array}$ & $\mathbf{V} \times \mathbf{T}$ & $\begin{array}{l}\text { Variety } \\
\text { (V) }\end{array}$ & $\begin{array}{l}\text { Treatment } \\
\text { (T) }\end{array}$ & $\mathbf{V} \times \mathbf{T}$ \\
\hline C.D. at $5 \%$ & NS & 0.46 & 0.93 & 1.16 & 1.18 & 2.37 & 1.17 & 1.32 & 1.66 & 2.13 & 2.67 & 3.01 \\
\hline S.Em. \pm & 0.21 & 0.15 & 0.30 & 0.55 & 0.39 & 0.78 & 0.38 & 0.27 & 0.54 & 0.70 & 0.86 & 0.99 \\
\hline
\end{tabular}

First flower bud opening: The maximum number of days for blooming of first flower buds was recorded (64.17 days) in Pavia and minimum (60.81 days) in Bach. However, the difference was statistically non-significant. Among the treatments, soil treated plants took maximum days 
(64.03) which was significantly higher than rest of the treatments. The flower bud opening was quickest (61.10 days) in cocopeat treated plants. Among interaction, Bach planted on cocopeat was quickest (59.33 days) in blooming whereas cv. Pavia raised on soil took maximum (66.53 days) in bud opening (Table 2). Similar findings were reported by Treder and Nowak (2002) in Pelargonium treated with cocopeat.

Table 2. Effect of growing media and variety on days to appearance of flower bud, days required for opening of first flower, total number of flower buds and vase life

\begin{tabular}{|c|c|c|c|c|c|c|c|c|c|c|c|c|}
\hline \multirow{2}{*}{ Treatments } & \multicolumn{3}{|c|}{$\begin{array}{l}\text { Days to appearance of flower } \\
\text { bud (day) }\end{array}$} & \multicolumn{3}{|c|}{$\begin{array}{l}\text { Days to first flower bud } \\
\text { opening (day) }\end{array}$} & \multicolumn{3}{|c|}{ Total number of flower buds } & \multicolumn{3}{|c|}{ Vase life (days) } \\
\hline & $\begin{array}{l}\text { Bach } \\
\text { (Vl) }\end{array}$ & $\begin{array}{l}\text { Pavia } \\
\text { (V2) }\end{array}$ & Mean & $\begin{array}{l}\text { Bach } \\
\text { (Vl) }\end{array}$ & $\begin{array}{l}\text { Pavia } \\
\text { (V2) }\end{array}$ & Mean & $\begin{array}{l}\text { Bach } \\
\text { (Vl) }\end{array}$ & $\begin{array}{l}\text { Pavia } \\
\text { (V2) }\end{array}$ & Mean & $\begin{array}{l}\text { Bach } \\
\text { (Vl) }\end{array}$ & $\begin{array}{l}\text { Pavia } \\
\text { (V2) }\end{array}$ & Mean \\
\hline Soil $\left(T_{1}\right)$ & 32.00 & 35.40 & 33.70 & 61.53 & 66.53 & 64.03 & 2.40 & 5.40 & 3.90 & 7.47 & 6.53 & 7.00 \\
\hline Cocopeat $\left(T_{2}\right)$ & 29.53 & 32.67 & 31.10 & 59.33 & 62.87 & 61.10 & 3.46 & 7.27 & 5.37 & 11.26 & 9.20 & 10.23 \\
\hline $\begin{array}{l}\text { Cocopeat }+ \\
\text { Sand }(1: 1)\left(T_{3}\right)\end{array}$ & 30.33 & 33.47 & 31.90 & 61.00 & 63.33 & 62.16 & 3.26 & 6.00 & 4.63 & 8.40 & 7.67 & 8.03 \\
\hline $\begin{array}{l}\text { Cocopeat }+ \text { Soil } \\
(1: 1)\left(T_{4}\right)\end{array}$ & 30.40 & 33.53 & 31.97 & 61.40 & 63.93 & 62.67 & 2.60 & 5.27 & 3.93 & 7.60 & 6.93 & 7.27 \\
\hline \multirow[t]{2}{*}{ Mean } & 30.57 & 33.77 & 32.17 & 60.81 & 64.17 & 62.49 & 2.93 & 5.99 & 4.46 & 8.68 & 7.58 & 8.13 \\
\hline & $\begin{array}{l}\text { Variety } \\
\text { (V) }\end{array}$ & $\begin{array}{l}\text { Treatment } \\
\text { (T) }\end{array}$ & $\mathbf{V} \times \mathbf{T}$ & $\begin{array}{l}\text { Variety } \\
\text { (V) }\end{array}$ & $\begin{array}{l}\text { Treatment } \\
\text { (T) }\end{array}$ & $\mathbf{V} \times \mathbf{T}$ & $\begin{array}{l}\text { Variety } \\
\text { (V) }\end{array}$ & $\begin{array}{l}\text { Treatment } \\
\text { (T) }\end{array}$ & $\mathbf{v} \times \mathbf{T}$ & $\begin{array}{l}\text { Variety } \\
\text { (V) }\end{array}$ & $\begin{array}{l}\text { Treatment } \\
\text { (T) }\end{array}$ & $\mathbf{V} \times \mathbf{T}$ \\
\hline C.D. at $5 \%$ & NS & 0.46 & NS & NS & 0.38 & 0.53 & NS & 0.30 & 0.42 & NS & 0.32 & 0.46 \\
\hline S.Em. \pm & 0.11 & 0.15 & 0.21 & 0.09 & 0.12 & 0.17 & 0.69 & 0.98 & 0.14 & 0.77 & 0.11 & 0.15 \\
\hline
\end{tabular}

Bud length, bud diameter, stem length.

Number of flower buds per plant: The data regarding number of flower buds per stem has been depicted in Table 2. Among the varieties, the number of flower buds was statistically at par. However, Pavia had more number of flower buds (5.99) than in cv. Bach, the minimum number of flower buds (2.93) was recorded. Among the potting mixture, the maximum number of flower buds (5.37) per stem was obtained in cocopeat treated plants which was significantly higher than rest of the treatments. The interaction effect was significant. Bach planted on soil showed minimum flower bud count (2.40), whereas maximum number of flower buds (7.27) was recorded in Pavia raised on cocopeat. Grassotti et al. (2003) also reported that coconut fiber used both singly or as a mixture, determined an increase in the number of lily buds. Asil (2008) reported that cultivating bed made up of peat and perlite increased number of floral buds, flowering time and chlorophyll content of leaves was significant in Asiatic hybrids of lilies (Amarone, Orlando, Pink Superior, Pollyanna, Salsa and Vignola).

Vase life: It is evident from the data that among the varieties, irrespective of potting media treatment, the maximum vase life (8.68 days) was observed in cv. Bach while the minimum vase life (7.58 day) was recorded in Pavia. However, the difference was non-significant. Among the treatments, maximum vase life (10.23 days) was reported in cocopeat treated plants which was significantly higher than rest of the treatments (Table 2). Among interaction, maximum vase life (11.26 days) was recorded in Bach planted on cocopeat, whereas Pavia 
raised on soil showed minimum vase life (6.53 days). Prisa et al. (2011) evaluated the use of organic or inorganic substrates for improving the vase life of Asiatic Lily. The results showed that the use of zeolites and Biomax determined a significant increase in flower longevity in the cultivar 'Original Love'. Maniram et al. (2012) reported that maximum longevity of spike (21.29 days) in gladiolus cv. White Prosperity was recorded with application of 2 ton/ha vermicompost.

\section{Conclusion}

In the light of aforesaid experimental finding, it may be concluded that among the different potting media treatments, $100 \%$ cocopeat $\left(\mathrm{T}_{1}\right)$ was found better for most of the parameters viz., plant height, early flower buds appearance, days required for opening of first flower, total number of flower buds and vase life.

\section{References}

Asil, M. H. (2008). Effects of growing medium on some postharvest characteristics of cut flowers in six cultivars of Asiatic hybrid lilies (Lilium longiflorum L.). Journal of Food, Agriculture \& Environment, 6(2), 442-446.

Beattie, D. J., \& White, J. W. (1992). Lilium - hybrids and species. In A. A. De Hertogh, \& M. L. Nard (Eds.), The Physiology of Flower Bulbs. Elsevier, Amsterdam.

Evans, M. R., Konduru, S., \& Stamps, R. H. (1996). Source variation in physical and chemical properties of coconut coir dust. Hortscience, 31, 965-967.

Grassotti, A., \& Burchi, G. (2011). Effect of different growing media on growth and development of two lilium (Oriental and Asiatic hybrids) types in soilless conditions. Acta Horticulturae, 900, 139-142.

Maniram., K. M., Malik, S., Singh, M. K., \& Pal, V. (2012). Impact of spacing, doses of vermi-compost and foliar application of salicylic acid on growth and flowering of Gladiolus (Gladiolus grandiflorus L.) cv. "White Prosperity". Annuals of Horticulture, 5(2), 272-279.

Moghadam, M. Z., \& Shoor, M. (2013). Effects of vermi-compost and two bacterial bio-fertilizers on some quality parameters of Petunia. Notulae Scientia Biologicae, 5(2), 226-231.

Prisa, D., Burchi, G., Antonetti, M., \& Teani, A. (2011). Use of organic or inorganic substrates for reducing the use of peat and improving the quality of bulbs and inflorescences in Asiatic lily. Acta Horticulturae, 900, 143-148. http://dx.doi.org/10.17660/ActaHortic.2011.900.17

Seyedi, N., Mohammadi, A., \& Allahyari, M. S. (2012). The impact of perlite and cocopeat as the growth media on Asiatic lilium. Asian Journal of Experimental Biological Sciences, 3(3), 502-505.

Shiravand, D., \& Rostami, F. (2009). Apartment and cut flowers (p. 259). Sarva press.

Tehranifar, A., Selahvarzi, Y., \& Alizadeh, B. (2011). Effect of different growing media on growth and development of two Lilium (Oriental and Asiatic Hybrids) types in soilless $\begin{array}{llll}\text { conditions. } \quad \text { Horticulturae, } & \text { 139-142. }\end{array}$ http://dx.doi.org/10.17660/ActaHortic.2011.900.16

Treder, J., \& Nowak, J. (2002). Zastosowanie podłoży kokosowych wuprawie roślin rabatowych. ZESZ. PROBL. POST. NAUK ROL, 485, 335-358. 


\section{Macrothink}

Tribulato, A., Noto, G., \& Argento, S. (2003). Soilless culture on quality production in lily. Acta Horticulturae, 614, 749-754. http://dx.doi.org/10.17660/ActaHortic.2003.614.111

\section{Copyright Disclaimer}

Copyright reserved by the author(s).

This article is an open-access article distributed under the terms and conditions of the Creative Commons Attribution license (http://creativecommons.org/licenses/by/3.0/). 